\title{
The Vulnerability of Nairobi to the Effects of Climate Change Between 1984 and 2016
}

\author{
Sunday Julius Abuje ${ }^{1}$, Bernard Moirongo Otoki², Bernard Mugwima Njuguna ${ }^{2}$, \\ Gerryshom Munala ${ }^{2}$ \\ ${ }^{1}$ Department of Landscape, Architecture, Jomo Kenyatta University of Agriculture and Technology (JKUAT), Nairobi, Kenya \\ ${ }^{2}$ Centre for Urban Studies, JKUAT, Nairobi, Kenya
}

Email address:

sunabuje@sabs.jkuat.ac.ke (S. J. Abuje)

\section{To cite this article:}

Sunday Julius Abuje, Bernard Moirongo Otoki, Bernard Mugwima Njuguna, Gerryshom Munala. The Vulnerability of Nairobi to the Effects of Climate Change Between 1984 and 2016. Landscape Architecture and Regional Planning. Vol. 5, No. 2, 2020, pp. 38-45.

doi: 10.11648/j.larp.20200502.14

Received: May 5, 2020; Accepted: June 12, 2020; Published: June 20, 2020

\begin{abstract}
Urban areas are exposed to compounded effects of climate change emanating from the confluence of a globally changing climate and the unique characteristics of urban climate. The unique urban climate is brought about by land cover patterns and the interaction between urban surfaces and weather elements. Among the recorded effects of this include the Urban Heat Island, increased surface runoff and altered wind flow patterns. Nairobi city has continued to experience these effects and it is projected that they may worsen under the changing climate. This study sought to establish the physical characteristics that make Nairobi City vulnerable to the climate change effects of flooding, to recommend adaptation measures. Nairobi City County watershed was the research situs. A descriptive research design was used to model runoff over two distinct periods of 1984 and 2016 using the Curve Number Method. The results pointed to a $162 \%$ increase in urban sprawl and a $45 \%$ increase in average rainfall for the corresponding period. The surface sealing from urban sprawl and the increasing surface runoff expose the city to a higher flooding risk. At the same time, the ecological services of green systems within urban areas are diminishing due to fragmentation of the green networks. It is recommended that urban development adopt a paradigm shift towards the use of green infrastructures like greenways, small urban green spaces and green roofs alongside water sensitive urban design approaches to adapt urban areas to the effects of climate change.
\end{abstract}

Keywords: Adaptation, Climate Change, Flooding, Land Cover, Nairobi

\section{Introduction}

There is compelling evidence that the global climate is changing faster than earlier predicted [6]. Urban areas are also rapidly growing, with over $60 \%$ of the world population projected to live in urban areas by the year 2030 [27]. Urban areas are therefore exposed to the compounded effects of climate change resulting from a combination of a globally changing climate, rapid urban growth, and the unique characteristics of urban climates. The unique urban climate is caused by land cover patterns and the interaction between urban surfaces and weather elements $[11,15]$ and [18].

The climate in urban areas manifests as, extreme rainfall, extreme winds, and extreme temperatures. Recorded effects of this include the Urban Heat Island (UHI), increased surface runoff and altered wind flow patterns. These make urban areas vulnerable to flooding and thermal stress. They are further worsened by climate change [23]. Climate change has led to an upward trend in the intensity and frequency of climate-related disasters since the 1950s. This increases the vulnerability of urban areas; [13, 14, 22] and [24].

Vulnerability is caused by among other factors, the urbanization process which changes the biophysical characteristic of urban areas. For instance, urbanization replaces forests, grasslands and streams with biologically deficient environments thereby affecting the climate, hydrology, and biodiversity [29] and [12].

With [3] argument that climate change is inevitable as we are past the tipping point, adaptation is paramount for the developing world since urbanization rates are highest there. 
This is significantly important for urban areas as they host some of the most vulnerable and largest population densities [26] and [27].

Global adaptation approaches vary but often revolve around the ecosystem and nature-based concepts. Several authors have underscored the role played by green urban systems in managing some of the climatic challenges such as flooding in urban areas [2, 9, 10, 16] and [21]. Urban planners, designers, and managers should, therefore, explore these measures to build urban resilience to flooding challenges.
The Nairobi city watershed comprises the Nairobi city county (NCC) and the three watershed systems. They originate outside the county boundary but pass through the city, the northern, and southern boundaries (Figure 1). The watershed is characterized by an undulating hilly topography with an elevation in a range of $1,460 \mathrm{~m}$ to $2300 \mathrm{~m}$ above sea level. The International Soil Reference and Information Centre's (ISRIC) classification of the soil drainage properties and depths point to a wide range of soil depths and drainage properties. This influences surface runoff volumes on areas without built-up land cover types.

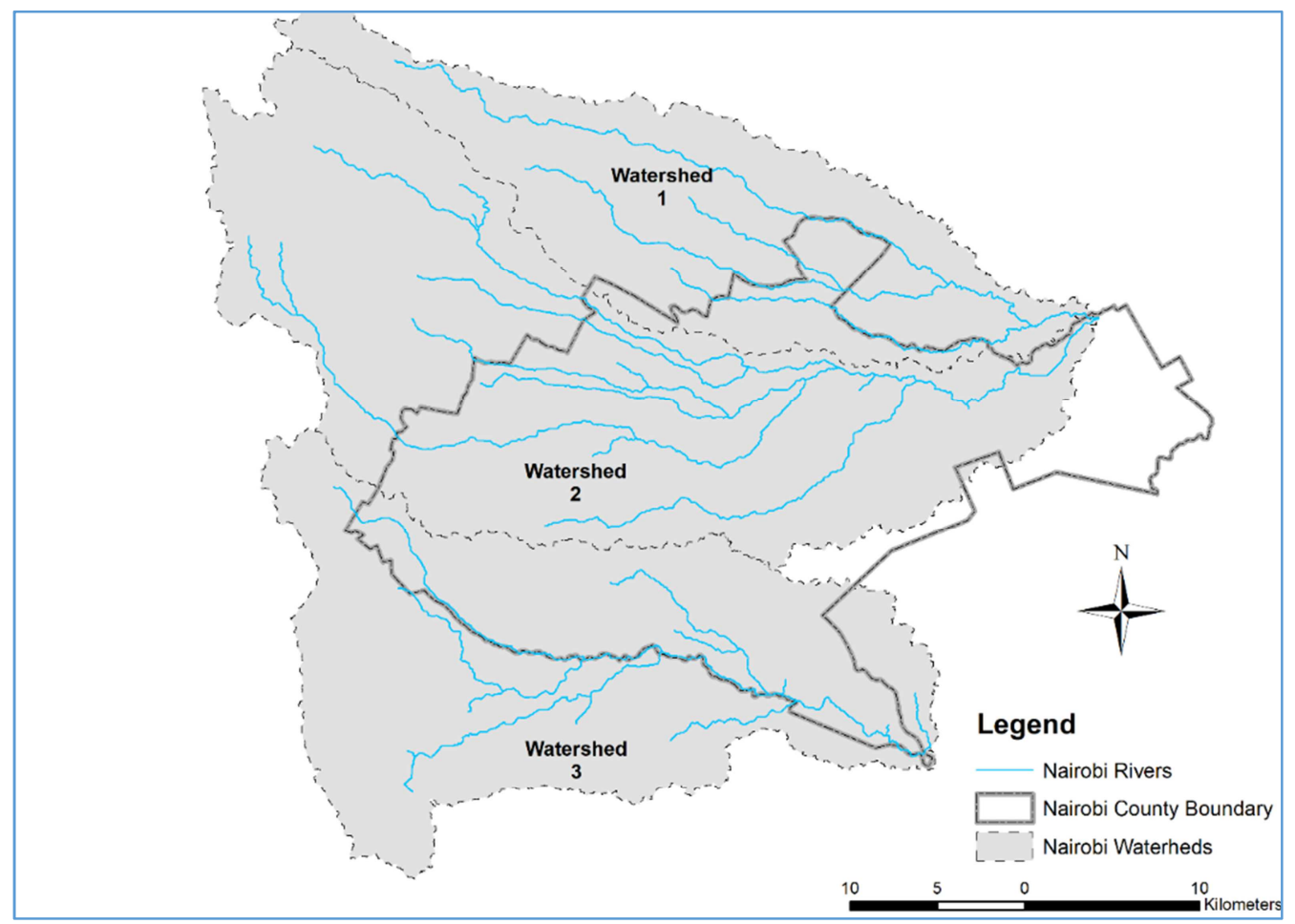

Figure 1. Nairobi City County Watershed showing the City-County boundary.

Nairobi city is the largest city in Kenya and among the fastest-growing cities in East and Central Africa. It has complex temporal and spatial distributions of population, infrastructure, and socio-economic activities. Rapid urbanization and reactive planning have increased pressure for infill high rise development in areas that were hitherto zoned and developed as the lower density. For instance, the neighbourhoods of Kileleshwa (Figure 2), Upper Hill (Figure 3), and Kilimani (Figure 4) have undergone tremendous infill development between the year 2002 and 2016. This has resulted in the increase of built-up land cover.
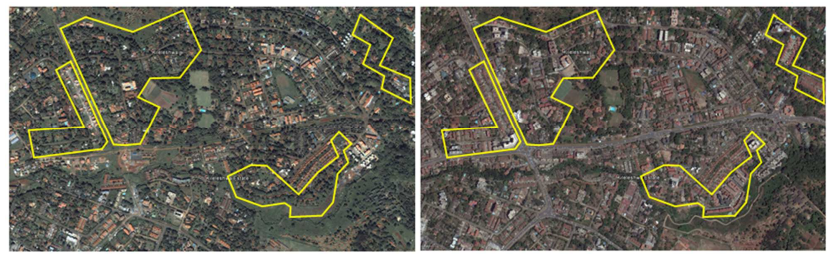

Figure 2. Kileleshwa Neighborhood in Nairobi. 2002 and 2016 respectively. Source (Google Earth).

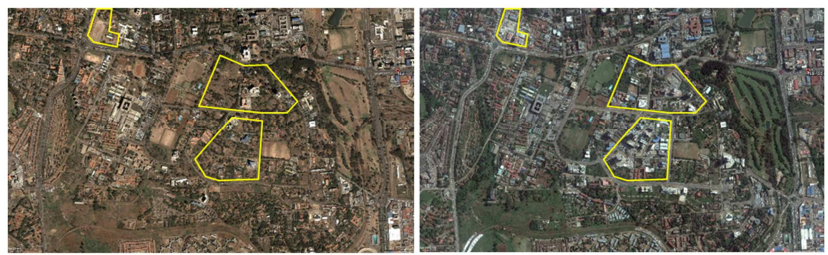

Figure 3. Upper hill Neighborhood in Nairobi. 2002 and 2016 respectively (Source: Google Earth).
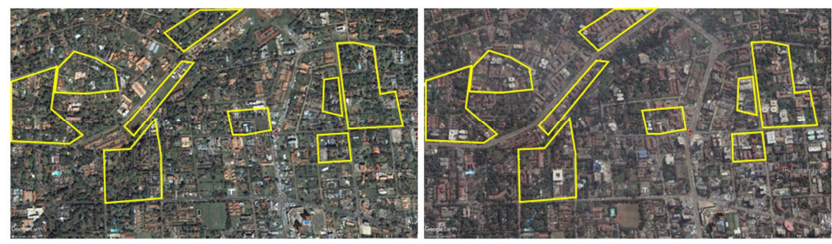

Figure 4. Kilimani neighbourhood in Nairobi. 2002 and 2016 (Source: Google Earth).

This urbanization process comes with changes in construction materials and an introduction of impervious surfaces. Building materials, especially in the Central 
Business District (CBD), and the emerging districts of Upper Hill and Westlands have also changed from concrete and stone (Figure 5) to glass facades (Figure 6) that reflect most of the solar radiation to the atmosphere thereby increasing air temperatures. The impervious surfaces reduce stormwater percolation, increasing runoff. This has resulted in about $43 \%$ chance of flooding every two years within the city [19]. Coupled with an overwhelmed drainage infrastructure, the city has been experiencing instances of flooding which worsen yearly. Despite the increased rainfall and flooding, rainwater harvesting, collection and retention in the city remains low even though the city is waster scares [17].

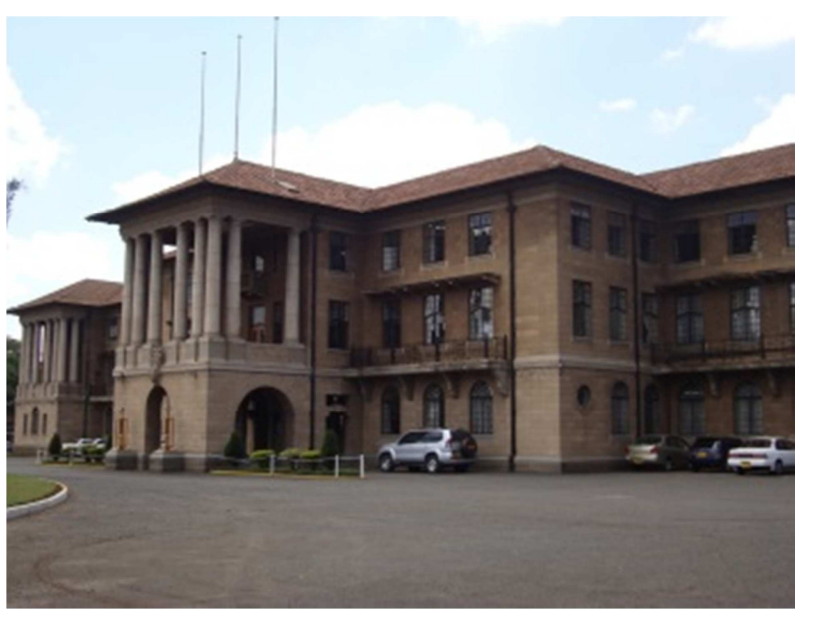

Figure 5. Character of older buildings in Nairobi. The Railway Station headquarters. Source (http://buildesign.co.ke/kenya-railways-headquartersbuilding/).

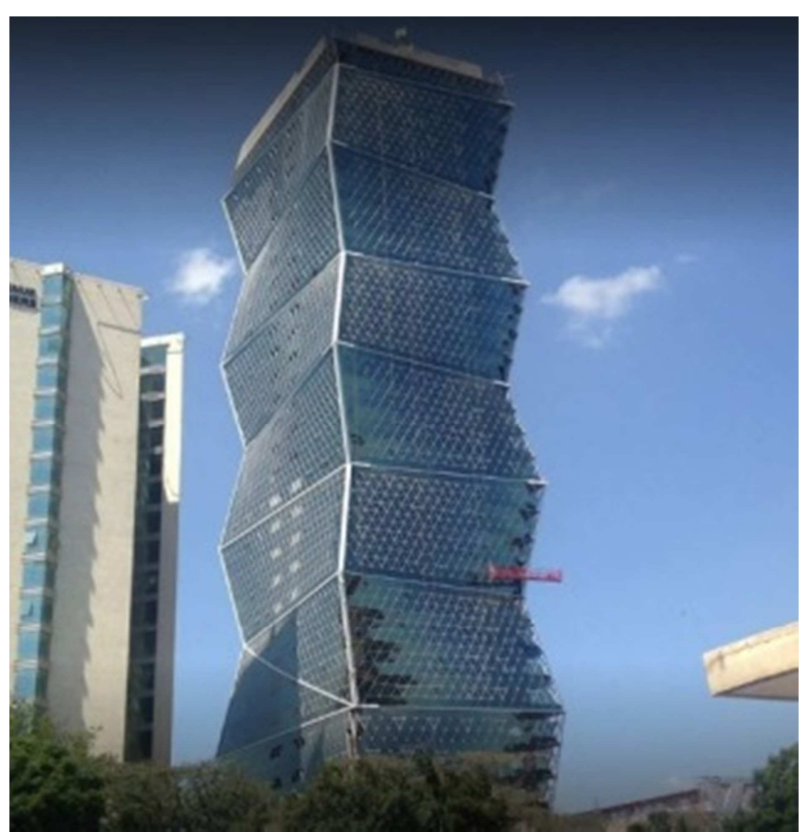

Figure 6. Character of new buildings in Nairobi. The Prism Towers. Source (https://www.synergyrealproperty.org/kings-prism-tower-upper-hill-areanairobi-kenya/).

\section{Method}

A descriptive research design augmented with Geographic
Information Systems (GIS), was used to model land cover types and surface runoff for 1984 and 2016. The landcover data was obtained from Landsat TM and ETM+ sensors for December 1984 and 2016, at a spatial resolution of $30 \mathrm{~m}$. The data was then classified through the supervised classification method. This yielded six land cover types namely: forest, Shrub and grassland, cropland, built-up area, bare ground, and open water. The selection of the 6 classes was based on the influence that these land cover types have on the interaction of weather elements like temperature and rainfall with urban surfaces $[1,5,8,10]$ and [20].

Surface runoff modelling used the Soil Conservation Service Curve Number (SCSCN) method commonly referred to as the Curve Number $(\mathrm{CN})$ method. The $\mathrm{CN}$ is a method used to determine runoff volumes in cases where runoff has not been directly measured. It estimates runoff by taking in to account the amount of rainfall, potential retention, and initial abstraction (Equation, 1 and 2). These aspects are determined by hydrologic soil groups, the land cover type, treatment, and the antecedent runoff condition [28].

$$
Q=\frac{\left(P-I_{\mathrm{a}}\right)^{2}}{P-I_{\mathrm{a}}}+S \#
$$

Where

$Q=$ runoff

$P=$ rainfall

$S=$ potential maximum retention after runoff begins

$I_{a}=$ initial abstraction

$$
S=\left(\frac{1000}{C N}\right)-10 \#
$$

Where:

$\mathrm{S}=$ potential maximum retention after runoff begins $\mathrm{CN}=$ Curve Number (Determined from the Curve Number table)

This method was selected as it uses rainfall volume in millimeters which is the unit used for rainfall data collection in the Nairobi watershed. The watershed extent and Land cover typologies were obtained from Remotely sensed data. Soil texture data was obtained from the Harmonized World Soil Database (HWSD) and corroborated using the Soil and Terrain Database (SOTER-Kenya). Annual average rainfall data was obtained from Climate Hazards Group Infrared Precipitation with Stations (CHIRPS). The soil textures (Figure 7) extracted from HWSD were those that influence water infiltration.

The entire watershed for Nairobi was used in the computation of surface runoff volumes. This covered the tributaries for all the key rivers that flow into the city. The Nairobi watershed was divided into 3 sub-watersheds (Figure 1). This was based on the flow of the rivers and their segregation. The runoff data from the different watershed polygons was finally weighted to allow for generalization across the entire watershed and the City. Even though watershed one and two eventually confluence, this happens at the boundary of the city-county. As such, their consolidation only impacts the next county 


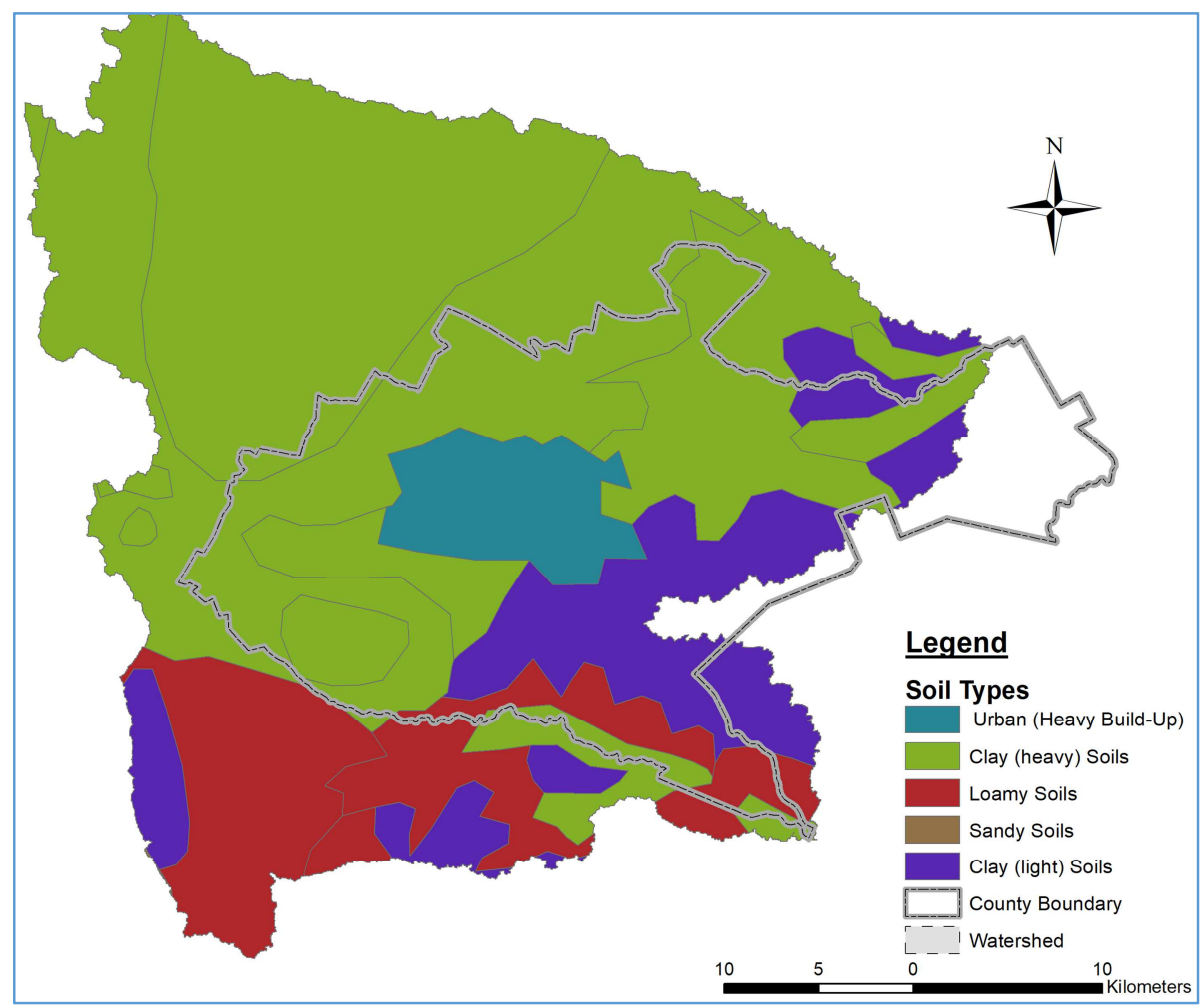

Figure 7. Soil Textures for the Nairobi City Watershed (Source: Developed from ISRIC)

\section{Results}

The trends of land cover changes between 1984 (Figure 8) and 2016 (Figure 9) show a mix of both increasing and decreasing land cover areas. This applies to both the city and the wider watershed where high rates of urban sprawl are experienced. At the watershed level, the highest land cover change is bare lands which increased by $1,561 \%$. The lowest change was a $15 \%$ reduction in the shrub and grassland cover. Forest, water, built-up and cropland all increased in a similar period (Table 1).

At the city level, the high rates of urban sprawl led to $162 \%$ increase in the built-up area. To accommodate the increasing built-up area, the shrub, and grassland reduced by $20 \%$ and cropland by $28 \%$ respectively (Table 1 ).

The average annual rainfall increased by $50 \%$ while the surface runoff increased by 390\% between 1984 and 2016 . The increases in runoff volumes for watershed 1, 2 and three were 391\%, 388\% and 394\% respectively (Table 2).

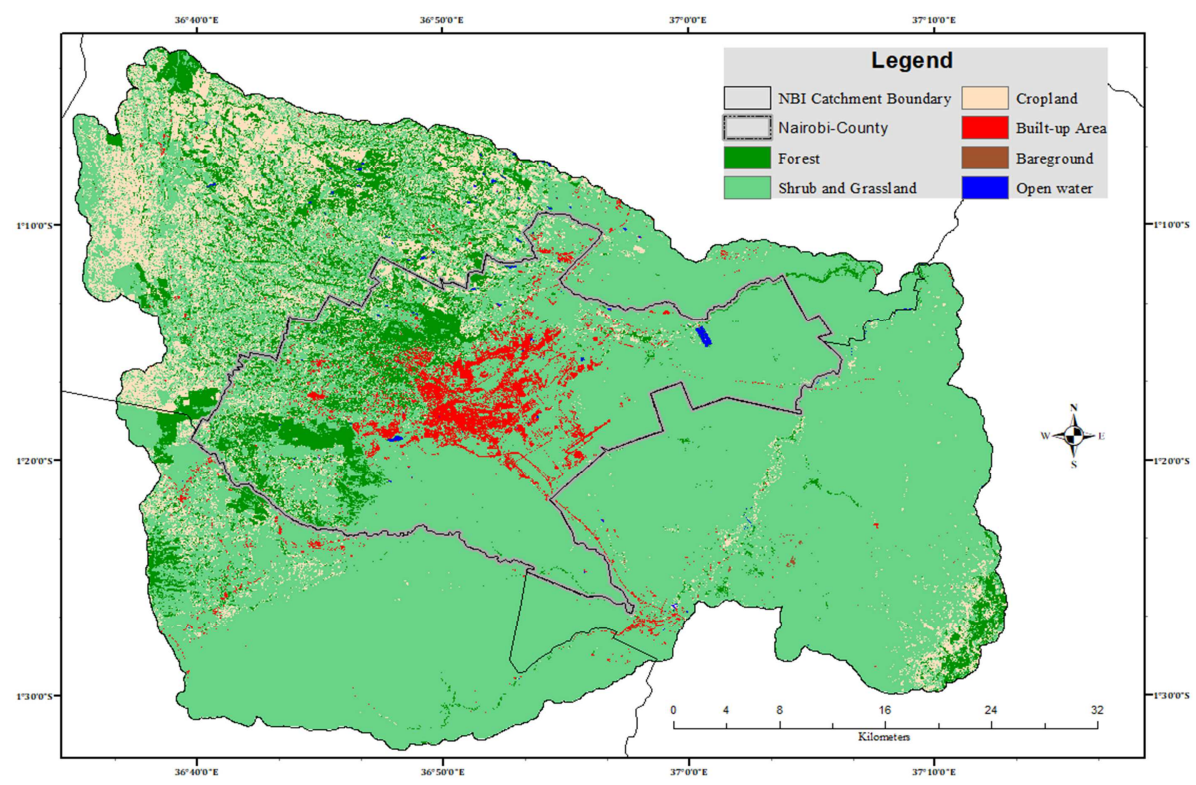

Figure 8. Land cover Typology Map of Nairobi County Watershed in 1984. 


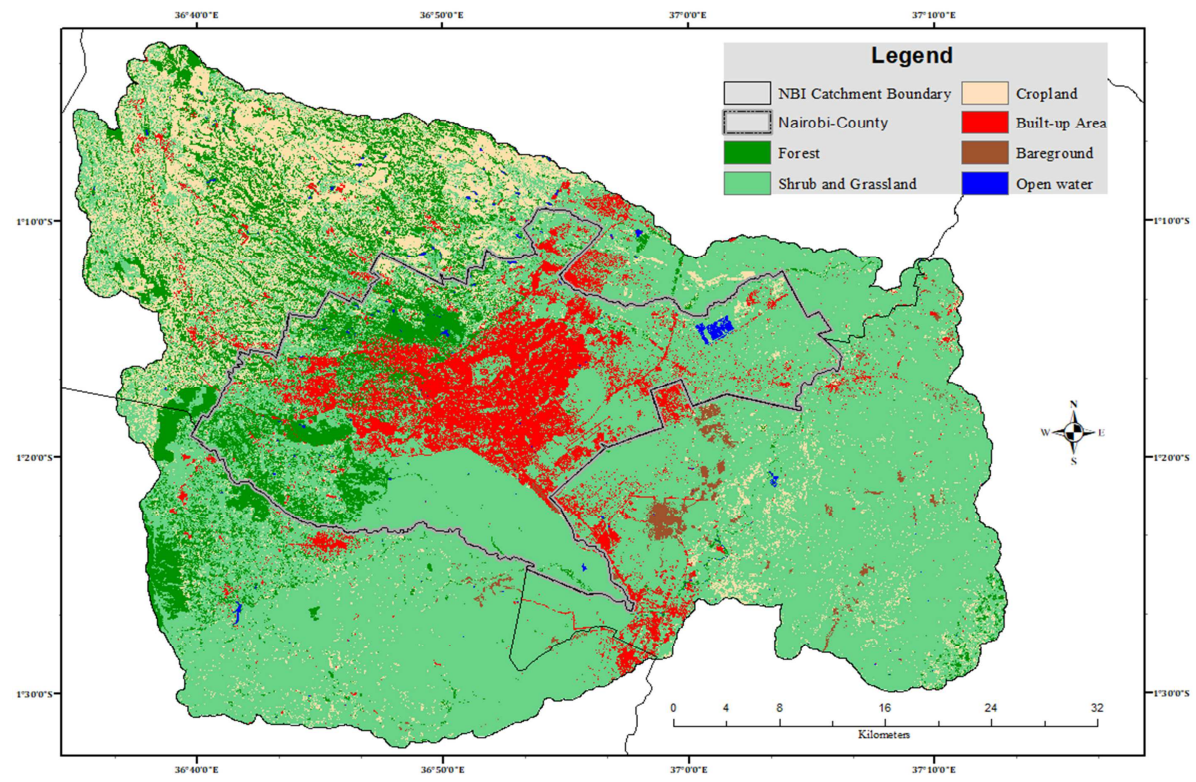

Figure 9. Land cover Typology Map of Nairobi County Watershed in 2016.

Table 1. Landcover Typology Areas in $\mathrm{Km}^{2}$ for Nairobi City County and the watershed in 1984 and 2016.

\begin{tabular}{lllllll}
\hline Land Cover & $\mathbf{2 0 1 6}$ N. C. C & $\mathbf{2 0 1 6}$ Watershed & $\mathbf{1 9 8 4}$ N. C. C & $\mathbf{1 9 8 4}$ Watershed & \% NCC Change & \% Change Watershed \\
\hline Forest & 105.35 & 327.92 & 100.05 & 275.16 & 5.30 & 19.17 \\
Shrub \& Grassland & 392.41 & 1659.87 & 493.24 & 1956.91 & -20.44 & -15.17 \\
Cropland & 28.16 & 358.32 & 39.16 & 296.65 & -28.09 & 20.78 \\
Built-up Area & 166.51 & 232.69 & 63.36 & 75.17 & 162.79 & 209.55 \\
Bare ground & 2.05 & 23.12 & 0.46 & 1.39 & 346.67 & 1561.15 \\
Open water & 3.84 & 7.14 & 2.06 & 3.79 & 86.31 & 88.34 \\
Total & 698.35 & 2609.09 & 698.35 & 2609.09 & & \\
\hline
\end{tabular}

Table 2. Summarized Computation of Runoff Volumes using the Curve Number Method.

\begin{tabular}{|c|c|c|c|c|c|c|c|c|c|}
\hline Year & W/shed & Area $\left(\mathrm{Km}^{2}\right)$ & $\begin{array}{l}\text { Rainfall } \\
(\mathrm{mm})\end{array}$ & Curve Number & $\begin{array}{l}\text { Run depth } \\
\text { (Q) }\end{array}$ & Weighted Q & $\begin{array}{l}\text { Runoff Volume } \\
\left(\mathrm{mill}^{\mathrm{3}} \mathrm{m}^{3}\right)\end{array}$ & Notes & $\begin{array}{l}\text { Total runoff } \\
\left(\mathrm{mm}^{3}\right)\end{array}$ \\
\hline \multirow{3}{*}{1984} & WS1 & 351.94 & 19.791 & 82.55 & 1.31 & \multirow{3}{*}{0.99} & 0.35 & \multirow{3}{*}{ City } & \multirow{3}{*}{1.54} \\
\hline & WS2 & 678.81 & 18.613 & 83.79 & 1.33 & & 0.68 & & \\
\hline & WS3 & 514.95 & 14.55 & 83.22 & 0.33 & & 0.51 & & \\
\hline \multirow{3}{*}{2016} & WS1 & 351.94 & 26.55 & 83.46 & 4.06 & \multirow{3}{*}{4.88} & 1.72 & \multirow{3}{*}{ City } & \multirow{3}{*}{7.56} \\
\hline & WS2 & 678.81 & 28.69 & 85.83 & 6.62 & & 3.32 & & \\
\hline & WS3 & 514.95 & 24.33 & 83.49 & 3.16 & & 2.52 & & \\
\hline
\end{tabular}

\section{Discussion}

Nairobi watershed and the city county have both undergone extensive sprawl between 1984 and 2016. Nonetheless, sprawl within the city county has been controlled by natural barriers such as the Nairobi national park to the south, Ngong road forest to the west and Karura forest to the north west. Outside the city county, other nuclei of growth include Mlolongo to the south, Ruiru and Kiambu towns to the north and Ongata Rongai town to the southwest.

The total area under forest and open water increased. The increase in forest area can be attributed to forest conservation efforts such as tree planting, fencing of forests and allowing for collaboration of communities in forest conservation and management. For instance, the Ngong Road Forest
Association and Friends of Karura Forest played a key role in conserving Ngong and Karura forests, respectively. This contributed to the increase in forest cover between 1984 and 2016. The increase in open water is at the sewerage treatment plant found in Ruai area. It has been expanded in two phases with the second phase falling within the period considered in the study. This phase was started in 1985 and completed in 1990.

Even though average annual rainfall increased by only $50 \%$ between 1984 and 2016, the surface runoff increased by about $390 \%$ for the same period. This pointed to the possibility of other drivers alongside rainfall. Since the soil patterns have not significantly changed, the other biophysical characteristics that could have played a role in increasing the runoff include increase in built-up area, reduction in grass and scrubland areas. As such, management of the runoff 
volumes require an approach that targets the biophysical character of the city.

\section{Conclusions}

Nairobi has experienced climate change. For instance, annual average rainfall has increased by $50 \%$ between 1984 and 2016. In the same period, the biophysical characteristics of the city have been changing. Impervious surfaces have increased by $162 \%$ leading to a reduction in green open spaces. A combination of the increased rainfall and imperviousness has increased the city's vulnerability to flooding by reducing the impact of ecological services. With the urbanization rates and climate change impacts projected to increase, the city's vulnerability to flooding can be expected to worsen. Therefore, to improve Nairobi's resilience to climate change, adaptation is paramount.

Due to the role-played rainfall, the soil textures and land cover typology in determining surface runoff, any efforts geared towards managing urban runoff in the city within the context of natural systems need to take all the three into account. With the exclusion of soil textures and rainfall, landcover is the part that can be modified through urban planning, design, and management to enable Nairobi's adaptation to climate change impacts.

\section{Recommendations}

The use of green and blue infrastructure is one such approach. These are interconnected networks of green space and water systems that conserve natural ecosystem values and functions and supply associated benefits to human populations [4] and [25]. Through incremental implementation, Nairobi can reduce its vulnerability to the effects of flooding by incorporating:

Permeable pavements. This will achieve both the need for paving of urban surfaces and permeability that is necessary for encouraging percolation. They will also improve the quality of percolated water through filtration and temperature reduction. The percolated water would be further beneficial for recharging the aquifer that supplies city wells and boreholes.

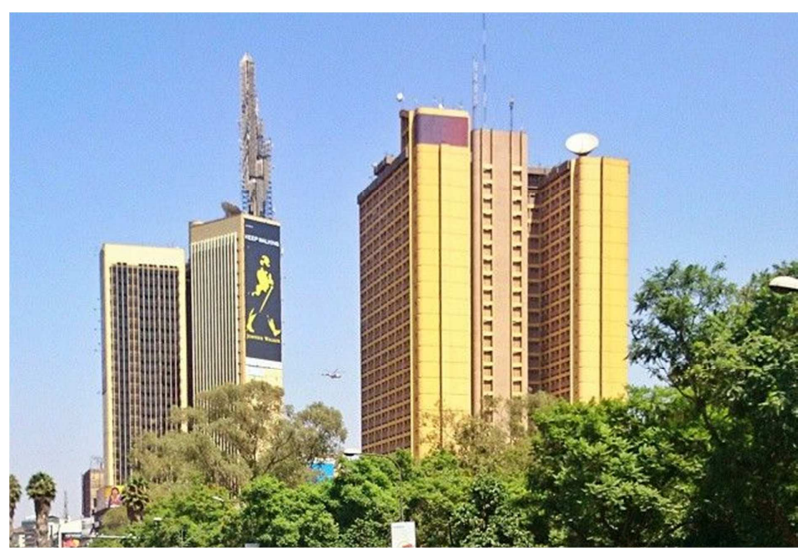

Figure 10. Teleposta Towers and Nyayo House.
Eco-Roofs and Walls. The city has potential for implementing eco roofs and walls in both existing and proposed buildings. Some of the high-rise buildings within the CBD such as Nyayo House, Teleposta Towers and Utalii House have flat roofs which with slight modification, can host extensive green roofs. These would manage runoff volumes and water quality.

Even though some buildings within the city have attempted to have green external walls using balcony and elevation planters such as Kimathi House and The Greenhouse, this can be scaled up to include larger balcony trees through façade design.

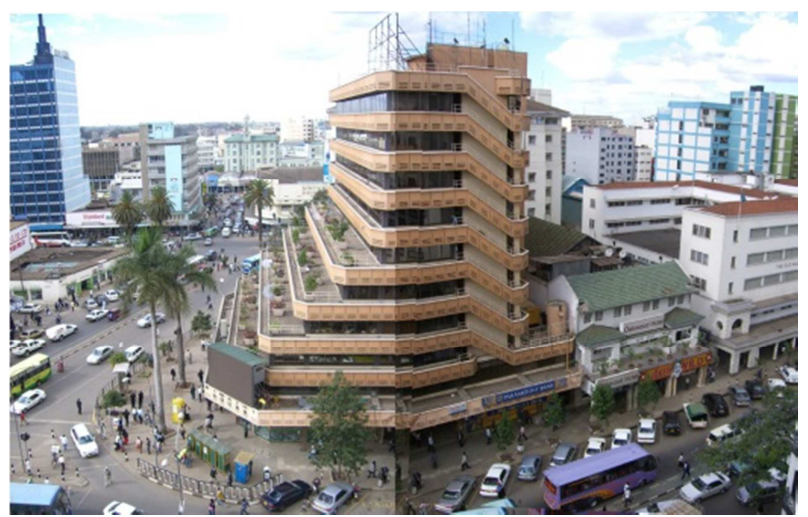

Figure 11. Kimathi house showing balcony planters. Source (https://www.nairaland.com/51356/nairobi-photos-kenya-beautiful-east/16).

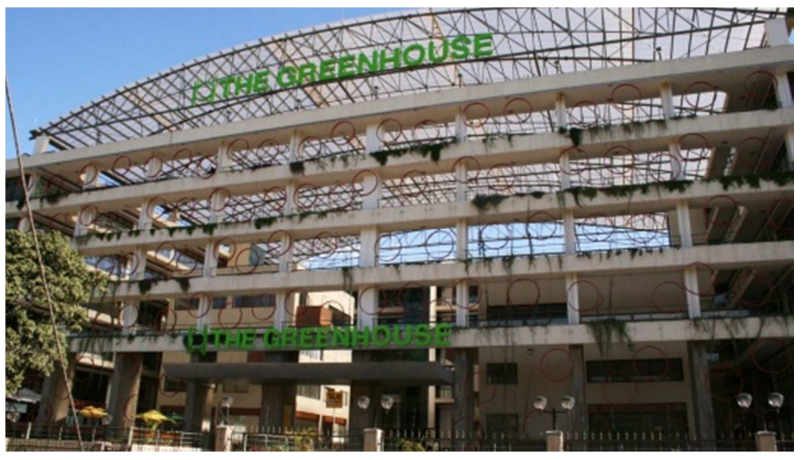

Figure 12. The Greenhouse showing green walls. Source (https://nairobifashionhub.co.ke/the-greenhouse-mall/).

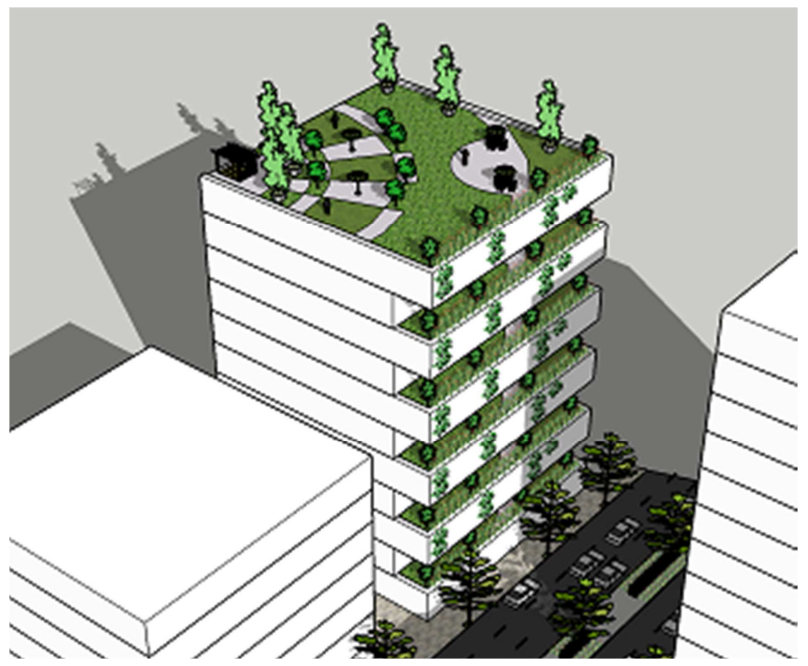




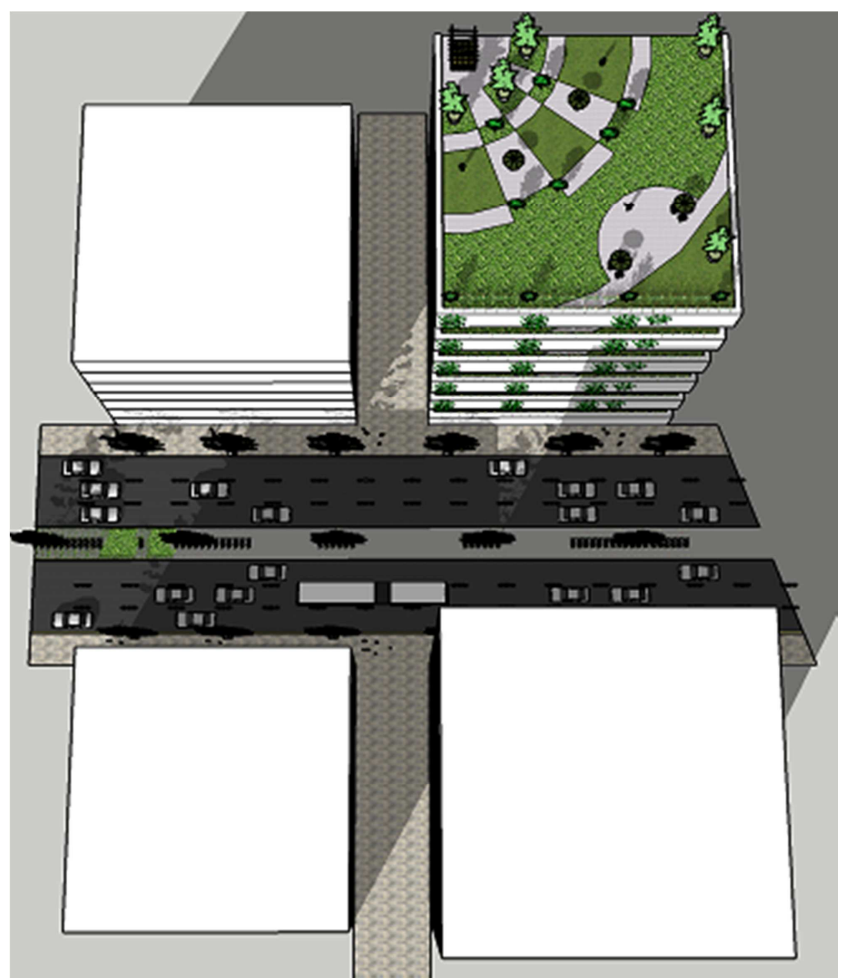

Figure 13. Sketches of Green Roofs and Walls.

Park, Plaza and Street Vegetation. Increasing the vegetation (trees, shrubs, and groundcovers) in urban parks and streets can minimize flooding risk through increasing permeable surfaces and reducing water speed. The slow speed of water provides more time for percolation.

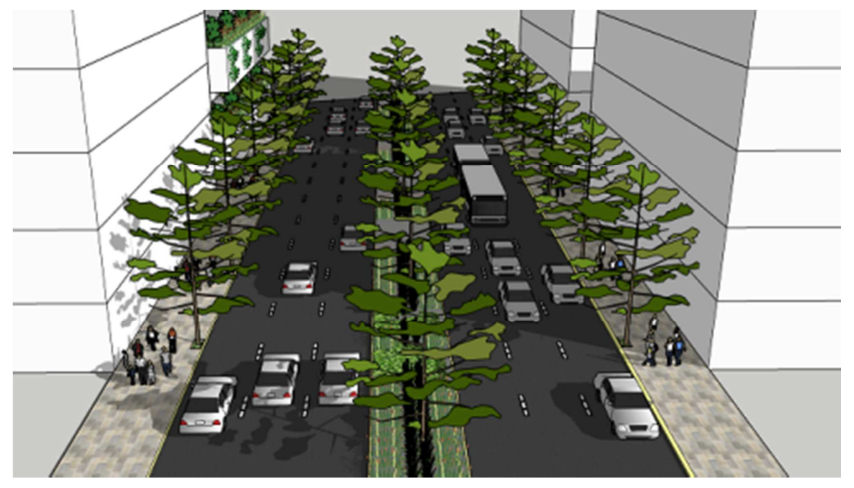

Figure 14. Sketch of Urban Greenways showing the use of street trees and green medians (Source: Author).

Nairobi City has several parks, plazas, and streets that with the infusion of vegetation (trees) would assist in reducing the cumulative runoff. Plazas such as City Square and National Archives, parks such as Uhuru Gardens and streets such as Kenyatta Avenue can be modified to improve their flood mitigation potential. This requires a shift in the design approach. For instance, tree planters and road medians need to be lowered to below the paved surface grade for this to work.

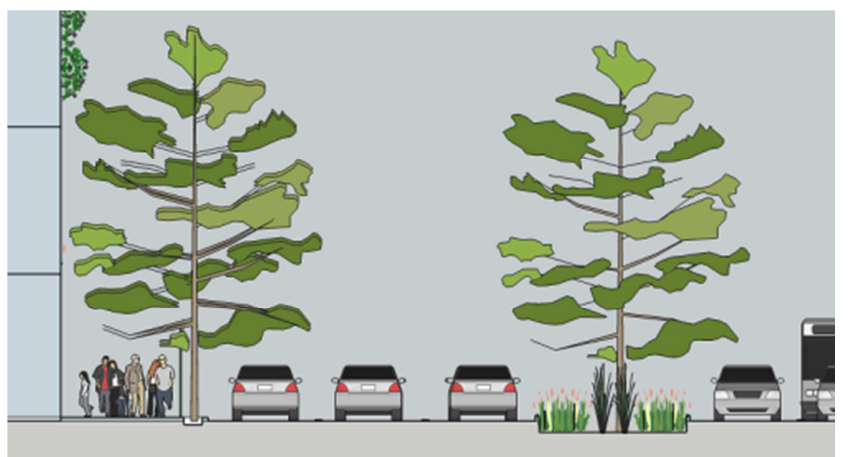

Figure 15. Sketch Section of Greenways showing lowered green systems such as medians and tree grates.

Water Sensitive Urban Design (WSUD). WSUD involves the collection, treatment, and storage of stormwater through features such as vegetated bio-retention systems, porous pavements, wetlands, bio-swales rainwater tanks, rain gardens, and stormwater ponds and subsequent distribution through irrigation. Rainwater collection, harvesting or retention within the city is low. Even though it is argued that some of the city by-laws prohibit harvesting, this can be reviewed especially within the context of a changing climate where water is becoming a challenge both in its volumes and in timing.

\section{References}

[1] Alam, K., Maghenda, M., McDonnell, Y., McLean, L., \& Campbell, J. (2009). Unjust Waters: Climate Change, Floodings and Urban Poor in Africa. In J. Bicknell, D. Dodman, \& D. Satterthwaite (Eds.), Adapting Cities to Climate Change: Understanding and Addressing the Development Challenges (pp. 201-218). London: Earthscan.

[2] Ali, M. (2013). The Contribution Of Urban Green Spaces In The Regulation Of The Microclimate And The Improvement Of The Air Quality In Cities. Asian Journal of Current Engineering and Maths, 2 (3), 190-195.

[3] Ashley, H., Kenton, N., \& Milligan, A. (Eds.). (2009). Participatory Learning and Action: Community-based adaptation to climate change. London: International Institute for Environmental Development.

[4] Benedict, M. A., \& McMahon, E. T. (2002). Green Infrastructure: Smart Conservation for the 21st Century. Renewable Resources Journal, 20 (3), 12-17.

[5] Bridgeman, H., Warner, R., \& Dodson, J. (1995). Urban Biophysical Environments. Melbourne: Oxford University Press.

[6] Brysse, K., Oreskes, N., O'Reilly, J., \& Oppenheimer, M. (2013). Climate change prediction: Erring on the side of least drama? Global Environmental Change, 23 (1), 327337.

[7] Coutts, A. M., Tapper, N. J., Beringer, J., Loughnan, M., \& Demuzere, M. (2012). Watering our cities: The capacity for Water Sensitive Urban Design to support urban cooling and improve human thermal comfort in the Australian context. Progress in Physical Geography, 37 (1), 2-28. 
[8] Erell, E., Pearlmutter, D., \& Williamson, T. (2011). Urban Micro-climate: Designing the Space between Buildings. New York: Earthscan.

[9] Foster, J., Lowe, A., \& Winkelman, S. (2011). The Value of Green Infrastructure for Urban Climate Adaptation. Washungton DC: Center for Clean Air Policy.

[10] Gill, S. E., Handley, J. F., Ennos, A. R., \& Pauliet, S. (2007). Adapting Cities for Climate Change: The role of Green Infrastructure. Built Environment, 33 (1), 115-133.

[11] Grimmond, C. S., Roth, M., Oke, T. R., Au, Y. C., Best, M., Betts, R.,... Voogt, J. (2010). Climate and More Sustainable Cities: Climate Information for Improved Planning and Management of Cities (Producers/Capabilities Perspective). Procedia Environmental Sciences (1), 247-274.

[12] Hough, M. (2002). City and Natural Process. New York: Routledge.

[13] IPCC. (2014a). Climate Change 2014: Impacts, Adaptation, and Vulnerability. Part A: Global and Sectoral Aspects. Contribution of Working Group II to the Fifth Assessment Report of the Intergovernmental Panel on Climate Change. (C. V. Field, Ed.) Cambridge: Cambridge University Press.

[14] IPCC. (2014b). Climate Change 2014: Impacts, Adaptation, and Vulnerability. Part B: Regional Impacts. Contribution of Working Group II to the Fifth Assessment Report of the Intergovernmental Panel on Climate Change. (C. B. Field, V. R. Barros, D. J. Dokken, K. J. Mach, M. D. Mastrandrea, T. E. Bilir,... L. White, Eds.) Cambridge: Cambridge Univerity Press.

[15] Lambin, E. F., \& Geist, H. (Eds.). (2006). Land-Use and Land-Cover Change: Local Processes and Global Impacts. Berlin, Heidelberg, New York: Springer.

[16] Landsberg, H. E. (1981). The Urban Climate. New York: Academic Press, Inc.

[17] Ledant, M. (2013). Water in Nairobi: Unveiling inequalities and its causes. Dynamiques urbaines (263), 335-348. doi: https://doi.org/10.4000/com.6951

[18] Littlefair, J. P., Santamouris, M., Alvarez, S., Dupagne, A., Hall, D., Teller, J.,... Papanikolaou, N. (2000). Environmental Site Layout Planning: solar access, microclimate and passive cooling in Urban Areas. London: BRE.
[19] Muli, N. M. (2011, November 7). Kenyatta University Institutional Repository. Retrieved January 10, 2018, from Kenyatta University: http://irlibrary.ku.ac.ke/handle/123456789/1597?show=full

[20] National Research Council. (2008). Urban Stormwater Management in the United States. Washington DC: The National Academies Press.

[21] Pattacini, L. (2012). Climate and Urban Form. Urban Design International, 17 (2), 106-114.

[22] Ramón, L., \& Thomas, V. (2015). Global Increase in ClimateRelated Disasters. Manila: Asian Development Bank.

[23] Satterthwaite, D., Huq, S., Pelling, M., Reid, H., \& Lankao, P. R. (2007). Adapting to Climate Change in Urban Areas: The possibilities and constraints in low- and middle-income nations. Human Settlements Discussion Paper Series. London: IIED.

[24] Sattethwaite, D., Huq, S., Reid, H., Pelling, M., \& Lankao, P. R. (2009). Adapting to Climate Change in Urban Areas: The possibilities and constraints in low and middle-income Nations. In J. Bicknell, D. Dodman, \& D. Satterthwaite (Eds.), Adapting Cities to Climate Change: Understanding and Addresing the development challenges (pp. 3-34). London: Earthscan.

[25] Shaw, R., Colley, M., \& Connell, R. (2007). Climate Change Adaptation by Design: A guide for sustainable Communities. London: TCPA.

[26] Solecki, W., Seto, K. C., Balk, D., Bigio, A., Boone, C. G., Creutzig, F.,... Zwickel, T. (2015). A conceptual framework for an urban areas typology. Urban Climate 14, 116-13.

[27] United Nations Department of Economic and Social Affairs. (2014). World Urbanization Prospects: The 2014 Revision. New York: United Nations.

[28] United States Department of Agriculture. (1986). Urban Hydrology for Small Watersheds Technical Release No. 55 (TR-55). Washington D. C.: USDA-SCS.

[29] Whitford, V., Ennos, A. R., \& Handley, J. F. (2001). "City Form and Natural Process" - Indicators for the Ecological Performance of Urban Areas and their Application to Merseyside, UK. Landscape and Urban Planning, 57, 91-103. 